\title{
THE INFLUENCE OF PROCESSING AND STORAGE CONDITIONS ON QUALITY PARAMETERS OF PUMPKIN PUREE
}

\author{
Solvita Kampuse*, Lolita Tomsone, Dace Klava, Liene Ozola, Ruta Galoburda \\ Department of Food Technology, Faculty of Food Technology, Latvia University of Life Sciences and Technologies, \\ Rigas iela 22, Jelgava, Latvia, e-mail: skampuse@inbox.lv
}

\begin{abstract}
The aim of this research was to investigate the influence of processing technology and storage conditions on the quality parameters of organic pumpkin 'Uchiki Kuri' puree. Pumpkin puree was produced industrially from organically grown cultivar 'Uchiki Kuri' by heating it in a heat exchanger, and treating through sieves. Obtained puree was used to prepare four different samples: sterilized sample, frozen sample, vacuum-cooked stored at room temperature, and vacuum-cooked stored at $4 \pm 2{ }^{\circ} \mathrm{C}$. Samples were stored for 26 weeks. During the storage period microbiological (yeasts, moulds, Lactic acid bacteria, and Enterobacteriaceae), and chemical (total carotenes, vitamin $\mathrm{C}$, total phenols, $\mathrm{DPPH}^{*}, \mathrm{ABTS}^{+}$, water activity, and $\left.\mathrm{pH}\right)$ parameters were analysed. Obtained results indicated that it is possible to store pumpkin purées up to six months, if those are sterilized at $110{ }^{\circ} \mathrm{C}$ for 15 minutes; frozen and stored at $-20 \pm 2{ }^{\circ} \mathrm{C}$; and vacuum-cooked, packed in a bag-in-box and stored at $4 \pm 2{ }^{\circ} \mathrm{C}$ temperature, preserving their microbiological safety. The total carotenes content in all samples (except samples stored at $22 \pm 2{ }^{\circ} \mathrm{C}$ in the bag-in-box packaging) were stable during storage for 26 weeks, while vitamin $\mathrm{C}$ content decreased twice already after four-week storage. Significant decrease of antiradical activity DPPH ${ }^{*}$ and ABTS $^{\circ}+$ after 26-week storage was observed as well.
\end{abstract}

Keywords: frozen, sterilized, vacuum-cooked, microbial quality, total carotenes, ascorbic acid, total phenols

\section{Introduction}

Pumpkin (Cucurbita maxima) fruit can be a healthy and valuable ingredient in a number of dishes and fruit products (Nawirska-Olszańska et al., 2014). One of the most popular pumpkin products - pumpkin puree is used as an ingredient for production of purees, jellies, jams, juices (Biesiada et al., 2011), and even confectionery and pastry products. This vegetable is particularly valuable due to high content of carotenoids, including $\beta$-carotene, lutein, and violaxantine (Biesiada et al., 2009), vitamin C (Biesiada et al., 2009), phenols (Dini et al., 2013), and carbohydrates (Chen, Huang, 2018). It is established that pumpkin regulates metabolism, lowers glucose level in blood, and possesses detoxicating effect (Song et al., 2018). Another attributed function of pumpkin species is defence against cancer (Nawirska-Olszańska et al., 2014). Therefore, it is very important to work on the development of technologies preserving valuable compounds.

Pumpkin products have low acidity. According to Nawirska-Olszańska et al. (2014) pH value of pumpkin cultivar 'Uchiki Kuri' was 7.17-7.46, which according to Jay et al. (2005) is favourable for growth of moulds, yeasts, Clostridium botulinum, Bacillus cereus, Salmonella spp., Listeria monocytogenes. Low-acid foods $(\mathrm{pH}>4.6)$ need to be sterilized $\left(>100{ }^{\circ} \mathrm{C}\right)$ because inhibiting effect of acidity on microbial flora is not present (Boz, Erdogdu, 2016). Pumpkin products possess very short shelf life. Therefore, processing methods such as - pasteurization, sterilization, freezing - are applied to extend the shelf-life. The choice of sterilization / pasteurization time is determined by temperature, chemical composition of the product, type of micro-organisms. However, application of high temperature treatment to fruit and vegetable products leads to degradation of many bioactive compounds (Taoukis et al., 1998).
As a good alternative to the high temperature treatment is frozen storage, which becomes more popular also for different semi-finished products (Skrupskis et al., 2017). Stability of physical, chemical and nutritional quality of foods is affected by various factors such as storage conditions and food matrix, including the initial microbial load and enzyme activity. Many studies have been conducted on storage stability of fruit products (Djaoudene, Louaileche, 2016), including stability of bioactive compounds (Skrovankova et al., 2015). However only few studies deal with storage stability of pumpkin puree.

Scientific researches are focusing on the use of various packaging materials and technological processes, with the aim extending the storage life without significantly altering the sensory properties of the product. One of such new packaging technologies is bag-in-box technology, which is very suitable for delivering bulk amounts of fruit and vegetable products for fast-paced institutional environments. There are very few or almost no investigations on the microbial safety and stability of bioactive compounds of fruit and vegetable products packed using bag-in-box technology.

The challenge for processing of vegetable products like pumpkins is to find a processing method which ensures a microbially safe product and as minimum 6 months shelf life with the highest contents of bioactive compounds. Therefore, the aim of this research was to investigate the influence of processing and storage conditions on the quality parameters of pumpkin 'Uchiki Kuri' puree.

\section{Materials and Methods}

Pumpkin puree preparation

Pumpkin puree from cultivar 'Uchiki Kuri' was produced industrially by washing, cutting, de-seeding, shredding in the cutter RM 2,2 (Voran Maschinen $\mathrm{GmbH}$, Austria), heating in the heat exchanger 
SCOOK10 (Tecmon Srl., Italy) at $90-96{ }^{\circ} \mathrm{C}$ for 2-5 min, and treating through a fruit puree extraction unit TPULP50 (Tecmon Srl., Italy). The obtained puree was divided into four batches, and further processed.

Frozen puree. Packaged in bag-in-box, cooled to room temperature, then frozen and stored in a freezer at $-20 \pm 2{ }^{\circ} \mathrm{C}$.

Sterilized puree. Heated till $75 \pm 2{ }^{\circ} \mathrm{C}$, filled in $250 \mathrm{~mL}$ glass jars, covered with caps and sterilized at $110{ }^{\circ} \mathrm{C}$ for 15 minutes in a pilot scale autoclave HST 50/100 (Zirbus technology, Germany). Stored in a dark place at $22 \pm 2{ }^{\circ} \mathrm{C}$.

Bag-in-box $22{ }^{\circ} \mathrm{C}$. Heat-treated at $76-80{ }^{\circ} \mathrm{C}$ for $25 \mathrm{~min}$ in a vacuum cooker EV-150 at 0.6 bar, with additional heating before filling $\left(93-94.6^{\circ} \mathrm{C}, 0.9\right.$ bar, holding time $10 \mathrm{~min})$. Stored in a dark place at $22 \pm 2{ }^{\circ} \mathrm{C}$.

Bag-in-box $4{ }^{\circ} \mathrm{C}$. Heat-treated as described above. Stored in a dark place at $4 \pm 2{ }^{\circ} \mathrm{C}$.

Microbiological analyses

Determination of the yeasts and moulds was completed according to ISO 21527-1:2008 $(n=5)$. Total plate count (TPC) was performed according to the standard LVS EN 4833:2003 (n=5). Analysis of Enterobacteriaceae was performed according to the standard LVS ISO 21528-2 $(n=5)$. Lactic acid bacteria (LAB) was detected in conformity with standard ISO 9332:2003 $(n=5)$.

\section{Physical and chemical analyses}

Determination of moisture content was done according to ISO 6496:1999. Samples were dried using Universal Oven UF55 (Memmert, Germany), at $105 \pm 1^{\circ} \mathrm{C}$ until constant weight $(\mathrm{n}=3)$.

Water activity $\left(a_{w}\right)$ was determined using LabSwift-aw (AG Novasina, Switzerland) equipment $(n=3)$.

$p H$ was measured $(\mathrm{n}=3)$ by $\mathrm{pH}$-meter (JENWAY 3510 , Baroworld Scientific Ltd., UK) using standard method LVS ISO 5542:2010.

Colour analysis were performed $(\mathrm{n}=5)$ using colour analyser ColorTec-PMC (Accuracy Microsensors, Inc., USA). The CIE L* $\mathrm{a}^{*} \mathrm{~b}^{*}$ colour system version 1976 was used.

The total carotenes content was detected by spectrophotometric method using UV/VIS spectrophotometer Jenway 6705 (Bibby Scientific Ltd., UK) and method described by Kampuse et al. (2015) with modifications. A sample of $2 \mathrm{~g}$ was mixed with $20 \mathrm{~mL}$ of ethanol on a magnetic stirrer for $15 \mathrm{~min}$. Further, $25 \mathrm{~mL}$ of petroleum ether were added and stirred for an hour. After mixing, samples were placed into darkness one more hour. The absorption of petroleum ether layer was measured at $440 \mathrm{~nm}(\mathrm{n}=3)$. The detection of ascorbic acid content. This method determines L-ascorbic acid, which is the reduced form of ascorbic acid, corresponding to the specimen after iodine method T-138-15-01:2002 (Seglina, 2007) $(n=4)$. The total phenol content was detected according to the Folin-Ciocalteu method (Yu et al., 2003) with modifications. A sample of $2 \mathrm{~g}$ mixed with ethanol: water solution $(80: 20 \mathrm{v} / \mathrm{v})$ was used for extract preparation (Priecina, Karklina, 2014). Absorption was recorded at $765 \mathrm{~nm}(\mathrm{n}=3)$ using a spectrophotometer JENWAY 6300 (Baroworld Scientific Ltd., UK). The obtained data were expressed as $\mathrm{mg}$ of gallic acid equivalent (mg GAE kg-1 of sample).

Determination of antiradical activity $\left(\mathrm{DPPH}^{\cdot}\right.$ and $\left.A B T S^{+}\right)$. The antiradical activity of extracts was measured on the basis of scavenging activities of the stable 2,2-diphenil-1-picrylhydrazyl (DPPH) free radical $\mathrm{Yu}$ et al. (2003) with modifications. To $0.5 \mathrm{~mL}$ of extracted sample, $3.5 \mathrm{~mL}$ freshly made $\mathrm{DPPH}^{*}$ solution was added; the mixture was shaken and kept in the dark place at $18 \pm 1{ }^{\circ} \mathrm{C}$ for $30 \mathrm{~min}$; absorbance was measured at $517 \mathrm{~nm}$ using JENWAY 6300 spectrophotometer $(n=3)$. The antiradical activity was expressed as mg Trolox equivalent (TE) $\mathrm{kg}^{-1}$ of sample (Priecina, Karklina, 2014).

The radical scavenging activity of extracts was measured by $\mathrm{ABTS}^{+}$radical cation assay as described by $\operatorname{Re}$ et al. (1999). A stock solution of 2,2'-azino-bis (3-ethylbenz-thiazoline-6-sulfonic) acid $\left(\mathrm{ABTS}^{+}\right)$ ( $2 \mathrm{mM}$ ) was diluted with phosphate buffered saline to obtain an absorbance of $(0.800 \pm 0.030)$ at $734 \mathrm{~nm}$. Then $5 \mathrm{~mL}$ of $\mathrm{ABTS}^{+}$solution was mixed with $0.05 \mathrm{~mL}$ of extract. The absorbance was read at ambient temperature $18 \pm 1^{\circ} \mathrm{C}$ after $10 \mathrm{~min}$. For both determinations of antiradical activity the obtained data were expressed as $\mathrm{mM}$ Trolox equivalents per $\mathrm{kg}$ of sample (Kruma et al., 2016).

All analyses were done at beginning and after 4, 7, 17, 24 and 26 weeks of storage, except ascorbic acid content, which was analysed up to $7^{\text {th }}$ week of storage, and DPPH antiradical activity, which was done up to $24^{\text {th }}$ week of storage. Each time two separate samples of puree were taken, and analyses were carried out in three to four replications.

\section{Statistical analysis}

The differences between the results were analysed using one-factor analysis of variance (ANOVA) followed by Tukey-Kramer method. The obtained results were presented as their means with standard errors. Differences among results were considered to be significant if $\mathrm{p}<0.05$.

\section{Results and Discussion}

The microbial quality

The selected processing methods were effective to reduce counts of lactic acid bacteria, moulds, and Enterobacteriaceae under the detection limit; and their growth was not observed in any of samples during the storage. As shown in Fig. 1, rapid increase of yeast counts was observed in a pasteurized pumpkin purée, which was stored at $22 \pm 2{ }^{\circ} \mathrm{C}$.

The development of yeast cells was delayed, when samples were stored at low temperatures, providing at least 6 months shelf life. When stored at $4 \pm 2{ }^{\circ} \mathrm{C}$ and frozen at $-20 \pm 2{ }^{\circ} \mathrm{C}$, yeast cells in pasteurised pumpkin purée are in anabiosis. In turn, the sterilized product is shelf-stable at room temperature $22 \pm 2{ }^{\circ} \mathrm{C}$ due to 
inactivating spores rather than only vegetative microorganisms (Knockaert et al., 2012).

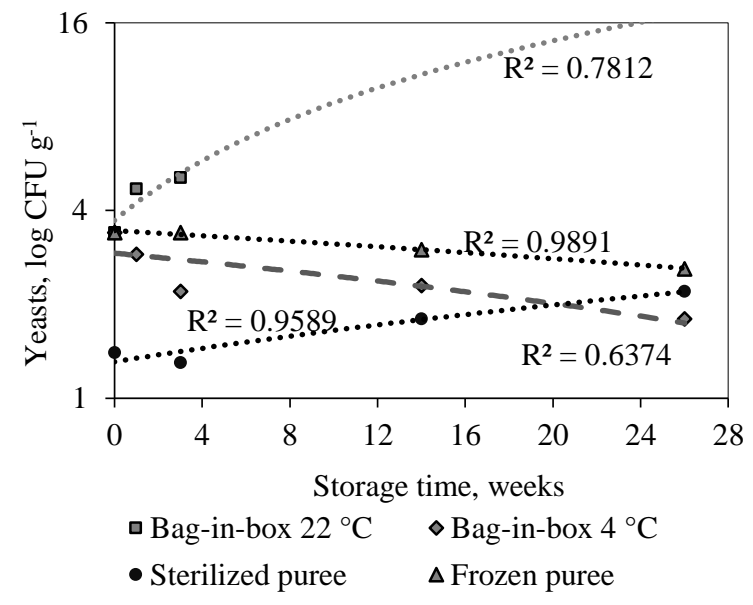

Figure 1. Yeast count in pumpkin puree during storage

An evaluation of total plate count in products (Fig. 2) showed a similar trend to yeasts.

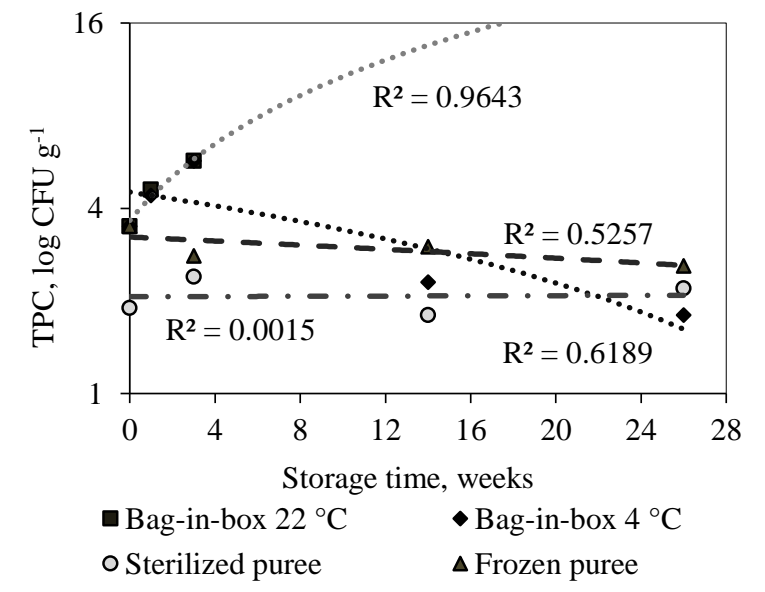

Figure 2. Total plate count in pumpkin puree during storage

Summarizing the obtained results of microbiological analysis, it was determined that the process of pasteurization and storage at room temperature $22 \pm 2{ }^{\circ} \mathrm{C}$ allows short-term storage - up to three weeks. In order to store the pumpkin puree up to six months and longer it is necessary to use the sterilization method, pasteurisation combined with refrigerated storage $4 \pm 2{ }^{\circ} \mathrm{C}$ or freezing.

\section{Water activity (aw)}

For a number of foods, it is important to perform tests on the amount of water activity (Fig. 3) in order to predict their stability and shelf life.

The water activity of the studied pumpkin samples was very high immediately after heat treatment (from 0.997-0.999), which testifies having good environment for the development of microorganisms. During storage of sterilized sample and sample stored at temperature $4 \pm 2{ }^{\circ} \mathrm{C}$ in the bag-in-box package, the water activity $\mathrm{a}_{\mathrm{w}}$ slightly decreased (up to 0.992 and 0.993 , respectively), although it did not have a significant effect on the growth of microorganisms.

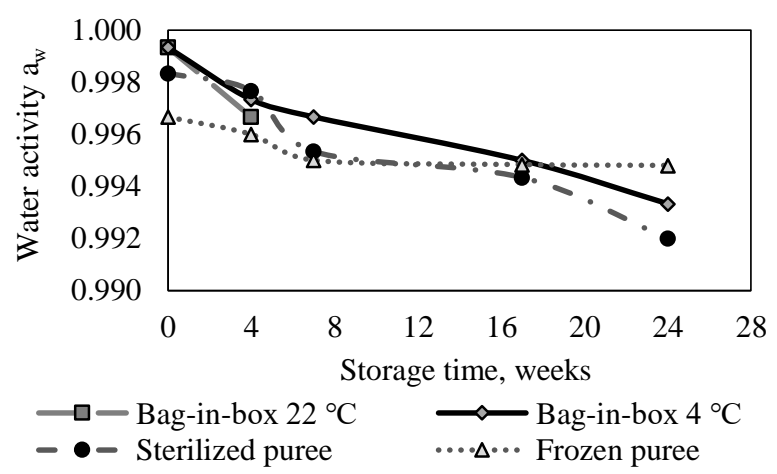

Figure 3. Water activity changes in pumpkin puree during storage

Changes of $\mathrm{pH}$

$\mathrm{pH}$ is the second most important indicator behind water activity, which characterizes the potential development of microorganisms. If the $\mathrm{pH}$ of the product is above 4.5, it is already considered as a potentially good environment for the development of spore-forming and pathogenic microorganisms (Boz, Erdogdu, 2016). The $\mathrm{pH}$ of the pumpkin pure was relatively high: from 6.2 to 6.6 at the beginning of storage to 5.9-6.2 after 6 months of storage (Fig. 4).

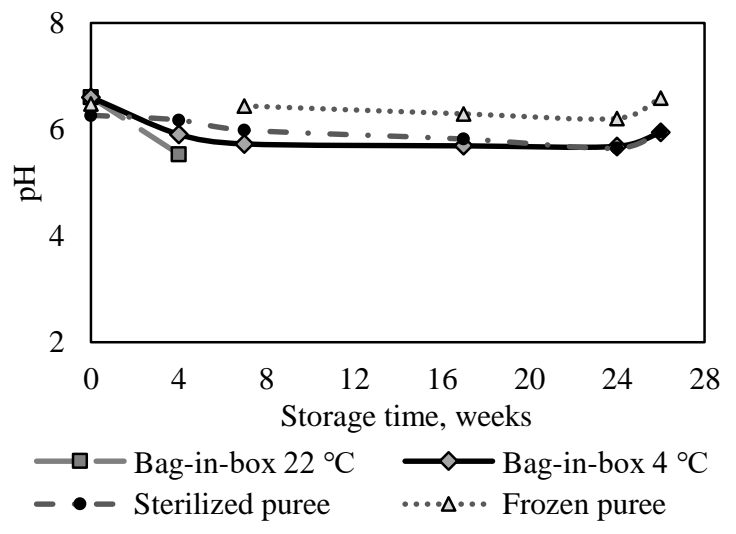

Figure 4. Changes of pH in pumpkin puree during storage

$\mathrm{pH}$ value of pumpkin cultivar 'Uchiki Kuri' in other investigations was mentioned even higher (7.17-7.46) (Nawirska-Olszańska et al., 2014). Such pH of the product is already close to the neutral $\mathrm{pH}$, thus it is a good environment for the development of various sporeforming microorganisms.

The changes of the $\mathrm{pH}$ during the storage of product can often indicate the onset of microbial deterioration, which was also observed at $22 \pm 2{ }^{\circ} \mathrm{C}$ in a bag-in-box package stored sample - after 4 weeks of storage the $\mathrm{pH}$ of the product had dropped till 5.5.

Decrease in $\mathrm{pH}$ was observed also for samples without microbial spoilage what could be explained by nonenzymatic oxidation processes and formation of other phenolic compounds (Castro-López et al., 2016) such as 
phenolic acids which could decrease the $\mathrm{pH}$ of product during storage.

Colour (CIE L* $\left.a^{*} b^{*}\right)$ changes

Comparing the colour of the pumpkin puree during storage, it was found that the colour of the sterilized purée had become lighter after 6 months of storage $\left(\mathrm{L}^{*}\right.$ value increased), while the purées stored at $4 \pm 2{ }^{\circ} \mathrm{C}$ had become slightly darker, but the colour intensity $\mathrm{L}^{*}$ of frozen purees did not change significantly $(p<0.05)$. The intensity of red colour for sterilized and frozen puree did not change significantly, but for puree stored at $4 \pm 2{ }^{\circ} \mathrm{C}$, slight increase in red colour intensity a* was observed that could be explained with non-enzymatic oxidation reactions which can influence such colour pigments as carotenes, flavones, and flavonones. According to Chisari et al. (2007), the oxidation of phenolic compounds to o-quinones may subsequently polymerize yielding dark pigments. The intensity of yellow colour component $b^{*}$ for all samples remained practically unchanged.

The slightest colour difference $\Delta \mathrm{E}$ (last day comparing to the first day) was for the frozen sample (2.6), but the biggest - for purée stored at $4 \pm 2{ }^{\circ} \mathrm{C}$ in the bag-in-box package (5.4), colour difference for sterilized puree was 3.8. The colour changes in the bag-in-box $4 \pm 2{ }^{\circ} \mathrm{C}$ packaging were considered as significant.

\section{Total carotenes}

The total carotenes content in all samples was stable during storage for 26 weeks except for samples stored at $22 \pm 2{ }^{\circ} \mathrm{C}$ in the bag-in-box packaging, which after 4 weeks of storage indicated a significant decrease $(p<0.05)$ of total carotenes (Fig. 5), what could be related to the microbiological spoilage.

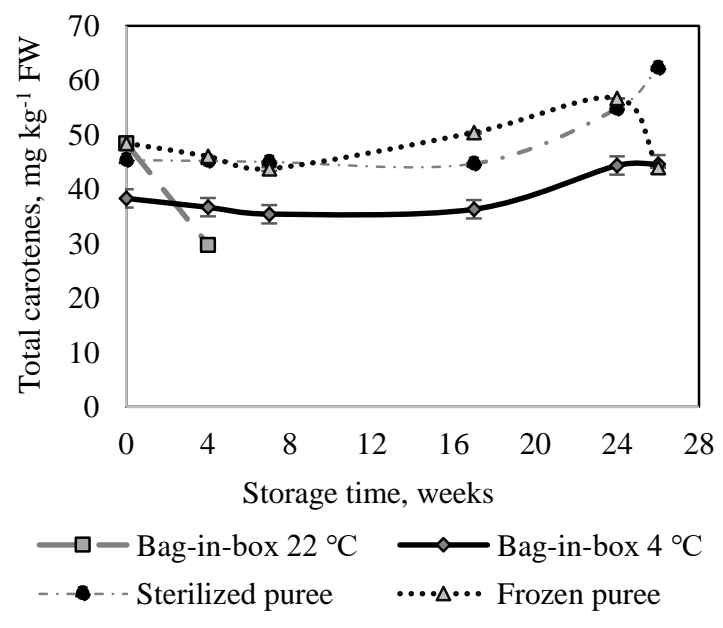

Figure 5. Changes of total carotenes content in pumpkin puree during storage

Provesi et al. (2011) in their research on carotenoid stability after processing and storage of pumpkin puree also revealed the stability of the major carotenoids. Heat processing is sufficient for the inactivation of enzymes and micro-organisms, which could degrade these compounds. Moreover, there is a partial vacuum inside the bottle because oxygen is removed from it and that allows to delay oxidation reactions. Storage at temperatures lower than $30{ }^{\circ} \mathrm{C}$ and protection from light are also important factors for the stability of carotenoids (Provesi et al., 2011). However, in other studies the losses of carotenoids after processing and storage were higher (Lin, Chen, 2005). Provesi et al. (2011) summarise that the stability of carotenoids in foods is variable. This happens not only because of extrinsic factors, such as the severity of heat treatment, presence or absence of light, temperature of storage, packaging, but also because of the characteristics of the food matrices, such as their chemical composition, the oxygen dissolved in the samples, size of the particles, and the physical state of the carotenoid in the food (Provesi et al., 2011).

\section{Ascorbic acid content}

After four weeks of storage, the content of vitamin C in all samples was reduced at least by half and practically reached the lowest limit of detection (36-54 mg per kg of product), therefore the evaluation of this parameter was discontinued after $7^{\text {th }}$ week of storage.

As it is known from many investigations, vitamin $\mathrm{C}$ is one of the most unstable vitamins. In experiments with different vegetables, blanching resulted in big ascorbic acid loss, but retention remained stable after freezing of broccoli and green beans. Green beans lost >90\% ascorbic acid after 16 days of storage. Linear decreases in ascorbic acid were found in most fresh-refrigerated and frozen vegetables during storage (Howard, 2008).

Our experiment showed that none of the storage conditions tested was sufficient for preserving the ascorbic acid in pumpkin puree packed in bag-in-box type packages.

\section{The total phenol content}

All studied samples showed a significant increase $(\mathrm{p}<0.05)$ in total phenol content (TPC) during storage (Fig. 6). TPC increased by $63.7 \%$, on average, during 26-week storage. During the first eight weeks of storage a significant increase of TPC was observed in all samples, which was followed by a gradual increase with the extension of storage time. Ghirardello et al. (2016) also observed increase of TPC in hazelnuts stored at $5{ }^{\circ} \mathrm{C}$ and relative air humidity $55 \%$. Unlike, Zhao et al. (2019) established TPC reduction in cherries stored at "near-freezing temperature (NFT) $0{ }^{\circ} \mathrm{C}$ ". Also authors Shiri et al. (2011) indicated the changes in the total phenolic content of fresh-cut grapes during storage. As their results showed, the phenolic content gradually increased during storage in both PET and PVC packaging. According to findings of these authors, phenolic compounds are generally synthesized by the shikimate pathway in which phenylalanine ammonialyase (PAL) is the key enzyme. The physical damage of plant tissue can increase PAL activity, which leads to an increase in phenolic compounds (Shiri et al., 2011). In an investigation of Castro-López et al. (2016) with processed juice beverages during storage $\left(4,8\right.$ and $\left.11^{\circ} \mathrm{C}\right)$ for 20 days, the TPC values in all samples also showed a tendency to increase from 
day 12. The authors have explained this phenomenon by a possible increment of polyphenolic compounds associated to the microbial growth or to reactions between oxidized polyphenols and formation of new compounds of antioxidant character during juice storage. They considered the possibility that during juice storage, some compounds could be formed and react with the Folin-Ciocalteu's reagent and significantly enhance the phenolic content as well.
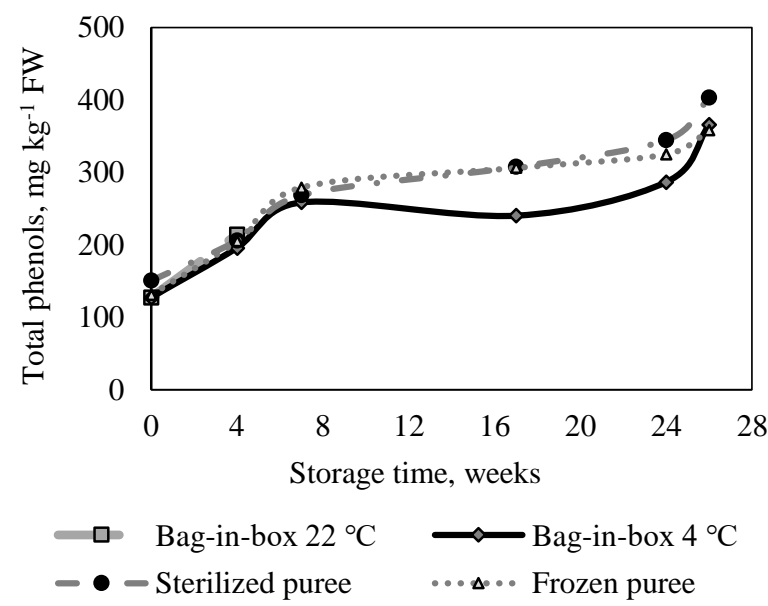

Figure 6. Changes of total phenol content in pumpkin puree during storage

There was no significant difference between TPC in samples, irrespective of storage conditions. Gradual increase was determined in frozen puree and sterilized puree after the week eighth. TPC in pumpkin puree packed in bag-in-box and stored at $4{ }^{\circ} \mathrm{C}$ did no change significantly between week 7 and week 17 , which was followed by more rapid increase starting from week 18 . The content of total phenols at the beginning of storage was 127.48 to $150.84 \mathrm{mg}$ per $\mathrm{kg}$ of sample. After 26 weeks or 6 months of storage, the total phenol content was 358.5-403.27 mg per kg of sample.

Antiradical activity / radical scavenging activity

The $\mathrm{DPPH}^{*}$ antiradical activity decreased slightly along the storage time. The most stable $\mathrm{DPPH}^{\circ}$ antiradical activity was in the bag-in-box sample stored at $4 \pm 2{ }^{\circ} \mathrm{C}$ (Fig. 7).

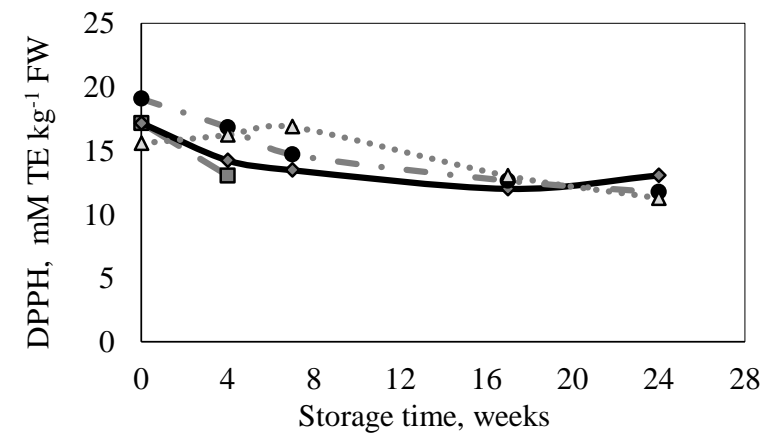

$$
\begin{aligned}
& - \text { Bag-in-box } 22{ }^{\circ} \mathrm{C} \quad \sim \text { Bag-in-box } 4{ }^{\circ} \mathrm{C} \\
& -\bullet-\text { Sterilized puree }
\end{aligned}
$$

Figure 7. DPPH' antiradical activity content in pumpkin puree during storage
The fastest decrease of $\mathrm{DPPH}^{\bullet}$ antiradical activity was in samples packed in bag-in-box bags after four weeks of storage at $22 \pm 2{ }^{\circ} \mathrm{C}$. After 24 weeks of storage, DPPH ${ }^{\circ}$ antiradical activity decreased by $30.0 \%$, on average, and it ranged from 19.78 to $23.43 \mathrm{mM}$ TE per $\mathrm{kg}$ fresh weight. Our results are in line with findings of Zhao et al. (2019), who reported the highest DPPH ${ }^{\circ}$ antiradical activity reduction rate in cherries stored at $5{ }^{\circ} \mathrm{C}$. Ghirardello et al. (2016) observed opposite trend in hazelnuts stored at $5{ }^{\circ} \mathrm{C}$ for 8 months. Storage conditions had significant effect on $\mathrm{ABTS}^{\circ}{ }^{+}$antiradical activity. The highest reduction of $\mathrm{ABTS}^{\circ+}$ antiradical activity was observed in a sterilized sample that was stored at room temperature (a decrease by 57.3\%). The most stable $\mathrm{ABTS}^{\cdot+}$ antiradical activity during the whole storage time was again in bag-in-box packed puree, which was stored at $4 \pm 2{ }^{\circ} \mathrm{C}$ (a decrease by $1.9 \%$ ) (Fig. 8).

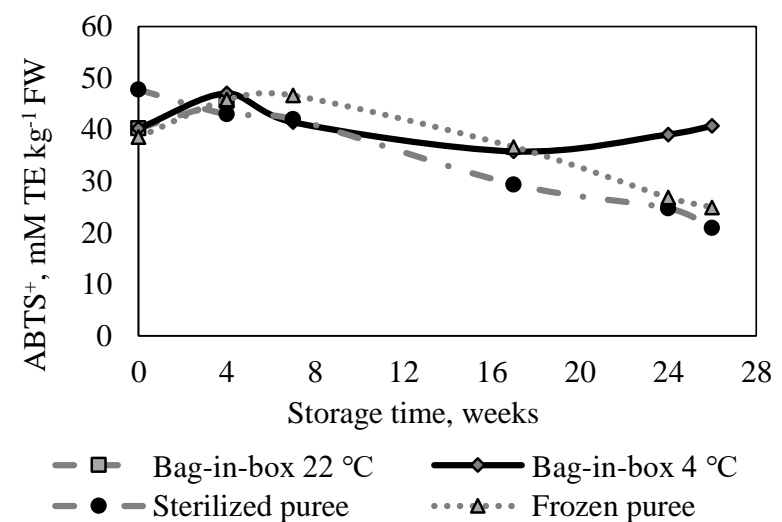

Figure 8. ABTS $^{\cdot+}$ antiradical activity in content in pumpkin puree during storage

Similar trend was revealed by Ghirardello et al. (2016), who studied hazelnut storage at $-25^{\circ} \mathrm{C}$. Contrary, ABTS $^{\circ+}$ antiradical activity increased after eighth months of hazelnut storage at $5^{\circ} \mathrm{C}$ and relative air humidity $55 \%$.

\section{Conclusions}

It is possible to provide microbial safety for pumpkin purées up to six months, if those are sterilized at $110^{\circ} \mathrm{C}$ for 15 minutes, frozen and stored at $-20 \pm 2{ }^{\circ} \mathrm{C}$, or packed in bag-in-box after vacuum-cooking and stored at $4 \pm 2{ }^{\circ} \mathrm{C}$. The total carotenes content was stable during storage for 26 weeks. None of the storage conditions tested was sufficient for preserving the ascorbic acid in pumpkin puree packed in bag-in-box type packages. All studied samples showed a significant increase in total phenol content (TPC) during storage. The $\mathrm{DPPH}^{\circ}$ antiradical activity decreased slightly along the storage time. The fastest decrease of $\mathrm{DPPH}^{-}$antiradical activity was in samples packed in bag-in-box bags after four weeks of storage at $22 \pm 2{ }^{\circ} \mathrm{C}$. The most stable $\mathrm{ABTS}^{\circ+}$ antiradical activity during the whole storage time was in bag-in-box packed puree, which was stored at $4 \pm 2{ }^{\circ} \mathrm{C}$. The biggest total colour difference was for puree stored at $4 \pm 2{ }^{\circ} \mathrm{C}$ in the bag-in-box package. Based on the 
results, the best methods for packaging and storage pumpkin puree are sterilization in glass jars and storage at room temperature and packaging in bag-in-box type packages and storage at $4{ }^{\circ} \mathrm{C}$ temperature.

\section{Acknowledgment}

This study was supported by 'SKAI BALTIJA' Ltd. (contract No SB/L - 1/17 (3.2-10/2017/LLU/2502.05.2017).

\section{References}

1. Biesiada A., Nawirska A., Kucharska A., Sokół-Łętowska A. (2009) The effect of nitrogen fertilization methods on yield and chemical composition of pumpkin (Cucurbita Maxima) fruits before and after storage. Vegetable Crops Research Bulletin, Vol. 70(1), p. 203-211.

2. Biesiada, A., Nawirska, A., Kucharska, A., SokółŁętowska, A. (2011) Chemical composition of pumpkin fruit depending on cultivar and storage. Ecological Chemistry and Engineering A, Vol. 18(1), p. 9-18.

3. Boz Z., Erdogdu F. (2016) Thermal processing: canning and aseptic packaging. In Y. H. Hui E. Özgül Evranuz (Eds.), Handbook of Vegetable Preservation and Processing (pp. 157-199). CRC Press.

4. Castro-López C., Sánchez-Alejo E. J., Saucedo-Pompa S., Rojas R., Aranda-Ruiz J., Martínez-Avila G. C. G. (2016). Fluctuations in phenolic content, ascorbic acid and total carotenoids and antioxidant activity of fruit beverages during storage. Heliyon, Vol. 2(9), p. 1-16.

5. Chen L., Huang G. (2018) Extraction, characterization and antioxidant activities of pumpkin polysaccharide. International Journal of Biological Macromolecules Biomac, Vol. 118, p. 770-774.

6. Dini I., Tenore G. C., Dini A. (2013) Effect of industrial and domestic processing on antioxidant properties of pumpkin pulp. LWT - Food Science and Technology, Vol. 53(1), p. 382-385.

7. Djaoudene O., Louaileche H. (2016) Impact of storage conditions on the bioactive compounds and antioxidant capacity of commercial orange jam. Journal of Analytical, Bioanalytical and Separation Techniques, Vol. 1(1), p. $8-11$.

8. Ghirardello D., Bertolino M., Belviso S., Dal Bello B., Giordano M., Rolle L., Vincenzo G., Antonucci M., Spigolon N., Zeppa G. (2016) Phenolic composition, antioxidant capacity and hexanal content of hazelnuts (Corylus avellana L.) as affected by different storage conditions. Postharvest Biology and Technology, Vol. 112, p. 95-104.

9. Howard L. (2008). Processing techniques and their effect on fruit and vegetable phytochemicals. In F. A. TomásBarberán, M. I. Gil (Eds.), Improving the HealthPromoting Properties of Fruit and Vegetable Products (pp. 449-472). Woodhead Publishing.

10. Jay J. M., Loessner M. J., Golden D. A. (2005) Modern Food Microbiology. Springer: New York, 790 p.

11. Kampuse S., Ozola L., Straumite E., Galoburda R. (2015) Quality parameters of wheat bread enriched with pumpkin (Cucurbita Moschata) by-products. Acta Universitatis Cibiniensis. Series E: Food Technology, Vol. 19(2), p. 3-14.

12. Knockaert G., Pulissery S. K., Colle I., Van Buggenhout S., Hendrickx M., Loey A. Van. (2012) Lycopene degradation, isomerization and in vitro bioaccessibility in high pressure homogenized tomato puree containing oil: Effect of additional thermal and high pressure processing. Food Chemistry, Vol. 135(3), p.1290-1297.

13. Kruma Z., Tomsone L., Galoburda R., Straumite E., Kronberga A., Åssveen M. (2016) Total phenols and antioxidant capacity of hull-less barley and hull-less oats. Agronomy Research, Vol. 14(Special Issue 2), p. 1361-1371.

14. Lin C. H., Chen B. H. (2005) Stability of carotenoids in tomato juice during storage. Food Chemistry, Vol. 90(4), p. 837-846.

15. Nawirska-Olszańska A., Biesiada A., Sokół-Łętowska A., Kucharska A. Z. (2014) Characteristics of organic acids in the fruit of different pumpkin species. Food Chemistry, Vol. 148, p. 415-419.

16. Priecina L., Karklina D. (2014) Natural antioxidant changes in fresh and dried spices and vegetables. International Journal of Biological, Biomolecular, Agricultural, Food and Biotechnological Engineering, Vol. 8(5), p. 492-496.

17. Provesi J. G., Dias C. O., Amante E. R. (2011) Changes in carotenoids during processing and storage of pumpkin puree. Food Chemistry, Vol. 128(1), p. 195-202.

18. Re R., Pellegrini N., Proteggente A., Pannala A., Yang M., Rice-Evans C. (1999) Antioxidant activity applying an improved ABTS radical cation decolorization assay. Free Radical Biology and Medicine, Vol. 26, p. 1231-1237.

19. Segliņa D. (2007) Sea buckthorn fruits and their processing products. Summary of promotion work for acquiring the Doctor's degree in Engineering Sciences in the Food Science. [accessed on 13.03.2019] Available at: http://llufb.llu.lv/dissertation-summary/food/Kopsa vilkums-2007-LLU-Dalija-Seglina.pdf

20. Shiri M. A., Ghasemnezhad M., Bakhshi D., Dadi M. (2011) Changes in phenolic compounds and antioxidant capacity of fresh-cut table grape (Vitis vinifera) cultivar "Shahaneh" as influence by fruit preparation methods and packagings. Australian Journal of Crop Science, Vol. 5(12), p. 1515-1520.

21. Skrovankova S., Sumczynski D., Mlcek J., Jurikova T., Sochor J. (2015) Bioactive compounds and antioxidant activity in different types of berries. International Journal of Molecular Sciences, Vol. 16(10), p. 24673-24706.

22. Skrupskis I., Blija A., Beitane I., Boca S., Aboltins A. (2017) Research of half-finished frozen berry products. In: 11th Baltic Conference on Food Science and Technology "Food science and technology in a changing world" FOODBALT 2017, p. 102-105.

23. Song J., Wei Q., Wang X., Li D., Liu C., Zhang M., Meng L. (2018) Degradation of carotenoids in dehydrated pumpkins as affected by different storage conditions. Food Research International, Vol. 107, p. 130-136.

24. Taoukis P. S., Panagiotidis P., Stoforos N. G., Butz P., Fister H., Tauscher B. (1998) Kinetics of vitamin C degradation under high pressure-moderate temperature processing in model systems and fruit juices. High Pressure Food Science, Bioscience and Chemistry, p. 310-316.

25. Yu L., Perret J., Harris M., Wilson J., Haley S. (2003) Antioxidant properties of bran extracts from "Akron" wheat grown at different locations. Journal of Agricultural and Food Chemistry, Vol. 51(6), p. 1566-1570.

26. Zhao H., Wang B., Cui K., Cao J., Jiang W. (2019) Improving postharvest quality and antioxidant capacity of sweet cherry fruit by storage at near-freezing temperature. Scientia Horticulturae, Vol. 246, p. 68-78. 